\title{
Investigation of a Potential Relationship Between Wild Bird Populations and Human Lyme Disease Rate in Connecticut from 1991-2002
}

\author{
Tamam Slam Abad Al-Ali ${ }^{1}$ \\ ${ }^{1}$ Ornithology from University of Oklahoma, USA \\ Correspondence: Tamam Slam Abad Al-Ali, Ornithology from University of Oklahoma, USA. E-mail: \\ tms_asa2008@yahoo.com
}

Received: January 14, 2017

Accepted: February 7, 2017

Online Published: February 15, 2017

doi:10.5539/ijb.v9n2p14

URL: http://dx.doi.org/10.5539/ijb.v9n2p14

\begin{abstract}
Lyme disease is the most common tick-borne disease in North America. Borrelia burgdorferi, is the pathogen, and the black-legged tick carries the bacteria and spreads it when feeding on the blood of animals and humans. At least 70 passerine species and one species of woodpecker in North American are parasitized by immature black-legged ticks. This hypothesis predicts that there would be a positive relationship between Lyme disease rates and bird numbers that infected with the pathogen, and there would be no relationship between Lyme disease rate and bird numbers that not known to be infected with the pathogen. The study depended on the North American Breeding Bird Survey (BBS) to get bird species for 14 routes across Connecticut, and on the Connecticut DHS to get Lyme disease rates for the time period of the study (1991-2002). The range of years was from 1991 to 2002 because of a change in how Lyme disease cases were reported starting in 2003. The bird data were: one group that included all 17 bird species that carry the pathogen, two species separately that are known to become infected by Lyme pathogen (American Robin and Gray Catbird), and a control species not known to carry the pathogen (American Redstart). The study found significant positive relationships between bird numbers and human Lyme disease rate in two routes for the SCLP group, one route for American Robin, three routes for Gray Catbird, and two routes for American Redstart. Only Gray Catbird had a significant negative relationship with human Lyme disease rate in one route. Based on the positive relationships that appeared for American Redstart, the control species, and the few significant relationships for birds known to carry the pathogen, the study rejected the hypothesis that there is a strong relationship between numbers of birds that could be infected with $B$. burgdorferi and the rate of Lyme disease in people as measured by the methods used in this study.
\end{abstract}

Keywords: Lyme disease, Lyme pathogen, black-legged tick, American Robin, Gray Catbird, American Redstart, Connecticut

\section{Introduction}

Lyme disease or Lyme borreliosis is a multi-system bacterial infection caused by spirochete bacteria called Borrelia burgdorferi senso lato complex. Lyme disease was first recognized in the United States in 1975 by Dr. Allen Steere, in the community of Lyme, Connecticut, but its cause was unknown until 1982. For cases reported in the United States to the Centers for Disease Control and Prevention (CDC), the average rate of Lyme disease in the ten states where it is most common was 31.6 cases for every 100,000 persons in 2005 . The arthropod that carries the pathogen and spreads it when feeding on the animal's blood is the black-legged tick. The Lyme disease pathogen, Borrelia burgdorferi sensu lato complex, is a spirochete bacterium from the genus Borrelia in the family Spirochetaceae. Not all the complex strains are pathogenic in humans, but the genospecies that can cause Lyme disease in North America is Borrelia burgdorferi sensu strico.

The black-legged tick (or deer tick), Ixodes scapularis, carries the bacteria and spreads it when feeding on the blood of animals and humans in north-central United States, and Western black-legged tick, Ixodes pacificus, does so in the western U.S. When the tick acquires the pathogen in a blood meal, the tick will remain infected even during its molting period, and it will be ready to transmit the pathogen to the mammalian host. When the ticks feed on the animals that carry B. burgdorferi in their blood stream (these animals are called reservoir hosts, such as the white-footed mouse), the ticks will be infected, and B. burgdorferi will be transmitted from the tick's saliva to 
humans by the tick's bite and cause Lyme disease.. Adult female I. scapularis transmits Lyme disease pathogen to humans during its feeding, but adult male does not transmit the pathogen because the time period for its attached is not long enough to make the transmission The vector black-legged tick lives in forests with rich and moist under growth protecting against dryness, Therefore, people working in forests are particularly exposed to these ticks". In the eastern United States, and the Infection with the Lyme disease pathogen has three stages, beginning with erythema migrans and ending with Lyme arthritis or memory loss.

Brinkerhoff and his colleagues (2011) found published records indicating that at least 70 passerine species and one species of woodpecker in North American are parasitized by immature black-legged ticks. . These studies indicated that the bird species that most parasitized by immature I. scapularis are thrushes, brown thrasher, wrens, and several species of wood warbler. Studies that have shown that bird species can become infected with $B$. burgdorferi, and thus dispersing and migrating birds have the ability to increase the ranges of B. burgdorferi and $I$. scapularis. Brinkerhoff indicated if $B$. burgdorferi strains that infect birds can also cause disease in humans.

The role of birds in Lyme disease could be very large (Brinkerhoff et al., 2011) stated that ticks derived from birds can influence $B$. burgdorferi transmission dynamics, either "by establishing new enzootic Lyme disease foci through the deposition of infected larval ticks ... or by dispersing infected larvae or nymphs that would then molt and parasitize humans.

\subsection{Hypothesis}

If birds play as an important role as reservoirs for dispersing Lyme disease, then there should be a positive relationship between the number of birds that have infection and the rate of Lyme disease in people. Also, the study would predict there is no relationship between Lyme disease rate and bird numbers for species not known to carry the pathogen.

The study chose Connecticut, a state in the New England region of the northeastern United States. Lyme disease was identified as a new disease in the town of Lyme in 1975 and today Connecticut still has a very high rate of the disease.

\section{Methods}

\subsection{Bird's Data:}

The study involved four groups. One group of birds included all 17 bird species that were found to be capable of being infected with B. burgdorferi-positive I. scapularis larvae (Species carrying Lyme pathogen, SCLP) (Table 1). The study also studied separately two species that are known to become infected by the Lyme pathogen: American Robin and Gray Catbird. Finally, the study used the American Redstart as a control species because at least two larvae were tested were not infected and thus this species may not be able to support the pathogen.

The American Robin (Turdus migratorius) is the largest thrush in North America (Cornell Lab of Ornithology n.d.). Male robins have rust-colored feathers on the chest, a yellow bill, a black head and white outlines around the eyes. Robins build a nest of grasses and middle layer of mud, lined with fine grasses, placed on horizontal limbs or shrub, tree, or on building). While American Robins are short distance migrants, some robins do not migrate. In fall, American Robins migrate in large flocks.

Gray Catbird (Dumetella carolinensis) is a species of mimid. It has a medium size with black cap and tail and a reddish brown patch under the base of the tail. Catbirds build their nest on horizontal branches hidden at the center of dense shrub, vines, and small trees (Cornell Lab of Ornithology. n.d). Gray Catbirds are Neotropical migrants.

The American Redstart (Setophaga ruticilla) is a unique warbler. The male is black with orange patches on the both wings, both sides of the breast, and at the base of its tail on either side. Redstarts nest in small trees or shrubs and use feathers and hair for lining, or they use other birds' nests. The nest is an open cup made of grasses, bark, and twigs with spider's silk. The American Redstart is an example of a bird with a wide migration route in North America because its route has an east to west width off about 2,500 miles.

To obtain an estimate of species populations, the study depended on the North American Breeding Birds Survey (BBS). The BBS IS international avian program initiated in 1966 to study North American bird populations. The study chose the 14 BBS routes (the Routes by their BBS ID number and name) through Connecticut towns that were active from 1991-2002. Each survey route is 24.5 miles long with stops at 0.5 -mile intervals. At each stop, a 3 -minute point count is conducted. 
Table 1. The 18 Passeriformes bird species used in this study. Seventeen species have the ability to be a vector for Lyme disease as shown by testing positive for Borrelia burgdorferi, and one species is not known to carry Borrelia burgdorferi. Based on Brinkerhoff et al. (2011). Nest and foraging location information are from the Cornell Laboratory of Ornithology (www.allaboutbirds.org).

* Passeriformes species known to carry Borrelia burgdorferi

\begin{tabular}{|c|c|c|c|c|}
\hline Family Name & Scientific Name & Common Name & Nest & Foraging \\
\hline Troglodytidae & Thryothorus ludovicianus & Carolina Wren & Cavity & Ground \\
\hline Troglodytidae & Troglodytes aedon & House Wren & Cavity & Foliage Gleaner \\
\hline Turdidae & Catharus fuscescens & Veery & Ground & Ground \\
\hline Turdidae & Catharus guttatus & Hermit Thrush & Ground & Ground \\
\hline Turdidae & Turdus migratorius & American Robin & Tree & Ground \\
\hline Mimidae & Dumetella carolinensis & Gray Catbird & Shrub & Ground \\
\hline Mimidae & Toxostoma rufum & Brown Thrasher & Shrub & Ground \\
\hline Parulidae & Mniotilta varia & Black-and-White Warbler & Ground & Bark Forager \\
\hline Parulidae & Helmitheros vermivorus & Worm-eating Warbler & Ground & Foliage Gleaner \\
\hline Parulidae & Setophaga citrina & Hooded Warbler & Shrub & Foliage Gleaner \\
\hline Parulidae & Parkesia noveboracensis & Northern Waterthrush & Ground & Ground \\
\hline Parulidae & Seiurus aurocapillus & Ovenbird & Ground & Ground \\
\hline Parulidae & Geothlypis trichas & Common Yellowthroat & Shrub & Foliage Gleaner \\
\hline Parulidae & Setophaga petechia & Yellow Warbler & Shrub & Foliage Gleaner \\
\hline Emberizidae & Melospiza melodia & Song Sparrow & Shrub & Foliage Gleaner \\
\hline Cardinalidae & Cardinalis cardinalis & Northern Cardinal & Shrub & Ground \\
\hline Cardinalidae & Pheucticus ludovicianus & Rose-breasted Grosbeak & Tree & Foliage Gleaner \\
\hline
\end{tabular}

* Control Passeriformes species not known to carry Borrelia burgdorferi

\begin{tabular}{|l|l|l|l|l|}
\hline Family Name & Scientific Name & Common Name & Nest \\
\hline Parulidae & Setophaga ruticilla & American Redstart & Tree & Foliage Gleaner \\
\hline
\end{tabular}

\subsection{Lyme Disease Rate}

To get the time period of the study for Lyme disease rates, the study depended on Lyme disease statistics from the Connecticut Department of Public Health. Rates are reported as cases per 100,000 people. The study range of years was from 1991 to 2002 because of a change in how Lyme disease cases were reported starting in 2003. (They were using physicians reporting, after 2003 they began use both physicians and laboratory tests). The data were by towns.

\subsection{Data Analysis}

Because the study was analyzing each route separately, the study needed to correct for multiple tests to avoid accepting as biologically significant a relationship that was actually simply due to chance (a Type I error). To do so, the study used the sequential Bonferroni technique (Rice, 1989), with a table-wide alpha level for statistical significance of 0.004 for analyses involving all 14 routes.

\subsection{Weather Data}

To get a sense about whether the weather affects Lyme disease rate, the study used data from weather stations close to each route from National Oceanic and Atmospheric Administration. Weather data were from 1991 to 2002. These files reported departure from normal monthly precipitation (DPNP) and departure from normal monthly temperature (DPNT) data as hundredths of an inch and tenths of a degree Fahrenheit. The study compared Lyme rate with annual DPNP and DPNT to see if there was a relationship, and the study used annual data because the Lyme disease rates are reported for full years. The study also checked to see if there was a relationship between DPNP and DPNT and bird numbers that were observed across years. The study focused on June because June is during the period when I. scapularis nymphs feed and when the bird surveys were made. 
Table 2. Observer identities for Connecticut Breeding Bird Survey routes used in this study. Routes that had statistically significant positive relationships between bird number and Lyme disease rate across all bird species are highlighted in bold. Data are from http://www.pwrc.usgs.gov/bbs/.

\begin{tabular}{|c|c|c|c|c|c|c|}
\hline Routes & 1991 & 1992 & 1993 & 1994 & 1995 & 1996 \\
\hline 001 Mystic & 1220021 & 1220021 & 1220021 & 1220021 & 1220021 & 1220021 \\
\hline 003 Buckingham & 1040203 & 1040203 & 1040203 & 1040203 & 1040203 & 1040203 \\
\hline 004 Uncasville & 1120202 & 1120202 & 1120202 & - & - & - \\
\hline 005 Woodstock & 990195 & 990195 & 990195 & 990195 & 990195 & 990195 \\
\hline 006 Westbrook & 1040289 & 1040289 & 1040289 & 1160112 & - & - \\
\hline 007 Willimantic & 990138 & 990138 & 990138 & 990138 & 990138 & 1040533 \\
\hline 008 Woodbury & 1090042 & 1090042 & 1090042 & 1090042 & 1090042 & 1090042 \\
\hline 009 Sherman & 1090154 & 1090154 & 1090154 & 1090154 & 1090154 & 1090154 \\
\hline 010 Greenwich & 1120147 & 1110084 & 1120147 & 1110084 & 1000323 & 1000323 \\
\hline 012 Warren & 1090042 & 1090042 & 1090042 & 1090042 & 1090042 & 1090042 \\
\hline 014 Mid Haddam & 1090166 & 1090166 & 1090166 & 1090166 & 1090166 & 1090166 \\
\hline 015 Southington & 1090398 & 1090398 & 1090398 & 1090595 & 1090595 & 1090595 \\
\hline 102 New Hartford & - & - & - & 1070245 & 1070245 & 1070245 \\
\hline 116 Granby & 1070073 & 1070073 & 1070073 & 1070073 & 1070073 & 1070073 \\
\hline Routes & 1997 & 1998 & 1999 & 2000 & 2001 & 2002 \\
\hline 001 Mystic & 1220021 & 1220021 & 1220021 & 1220021 & 1220021 & 1220021 \\
\hline 003 Buckingham & 1090398 & 1090398 & 1090398 & 1090398 & 1090398 & 1090398 \\
\hline 004 Uncasville & 990195 & 990195 & 990195 & 990195 & - & 990195 \\
\hline 005 Woodstock & - & - & - & - & - & - \\
\hline 006 Westbrook & - & 1160112 & 1160112 & - & - & - \\
\hline 007 Willimantic & 1040533 & 1040533 & 1040533 & 1040533 & 1040533 & 1040533 \\
\hline 008 Woodbury & 1090042 & $1090042 *$ & 1140406 & 1140406 & 1140406 & 1140406 \\
\hline 009 Sherman & 1090154 & 1090154 & 1090154 & 1090154 & 1090154 & 1090154 \\
\hline 010 Greenwich & 1000323 & 1000323 & 1000323 & 1000323 & - & - \\
\hline 012 Warren & 1090042 & 1140406 & 1140406 & 1140406 & 1140406 & 1140406 \\
\hline 014 Mid Haddam & - & - & - & - & - & - \\
\hline 015 Southington & 1090595 & 1090595 & 1090595 & 1090595 & 1090595 & - \\
\hline 102 New Hartford & 1070245 & 1070245 & 1070245 & 1070245 & 1070245 & 1070245 \\
\hline 116 Granby & - & - & - & - & - & - \\
\hline
\end{tabular}

*This is most likely to be an error and should be observer 1140406 based on large increases in the number of birds counted in 1998 compared to 1997.

\section{Results}

The highest Lyme disease rate was recorded for 009 Sherman in 2002 (1,197.8 per 100,000 people), while no cases of Lyme disease were recorded for 116 Granby in 1994. Across the range of years that the study focused on, the study found an increase in Lyme disease rates (Table 3). Generally, in 1991 mean Lyme disease rate was lower than other years (mean rate was 89.8 per 100,000 people), while 2002 recorded the highest mean rate of Lyme disease (mean rate was 362.4 per 100,000 people).

Across the 14 routes, the two highest mean Lyme disease rates per 100,000 people were for 005 Woodstock (mean rate was 490.9) and 009 Sherman (mean rate was 490.9). The two routes with the lowest mean Lyme disease rate per 100,000 people were 015 Southington (mean rate was 24.9) and 116 Granby (mean rate was 28.4).

The study checked if the weather conditions departing from normal measurements affected Lyme disease rates and the number of birds that were observed across years. Neither annual departure from normal precipitation (DPNP) nor annual departure from normal temperature (DPNT) (Table 4) had a strong effect on Lyme disease rate for all routes because the study found no statistically significant regression results after applying the Bonferroni correction technique. Similarly, the study did not find any significant relationship between June DPNP (Table 5), or June DPNT (Table 6) and the number of birds counted because there was again no statistically significant regression after applying the Bonferroni correction technique. 
Table 3. Lyme disease rates by Breeding Bird Survey route. Data are from Connecticut Department of Public Health. Highest and lowest individual rates are two highest and lowest mean rates are underlined.

\begin{tabular}{|l|l|l|l|l|l|l|l|}
\hline Routes & 1991 & 1992 & 1993 & 1994 & 1995 & 1996 & 1997 \\
\hline 001 Mystic & 39.3 & 54.3 & 49.0 & 121.8 & 114.8 & 177.8 & 168.0 \\
\hline 003 Buckingham & 138.3 & 290.8 & 303.3 & 312.8 & 227.8 & 323.5 & 304.5 \\
\hline 004 Uncasville & 181.4 & 190.8 & 179.2 & 161.3 & 176.0 & 408.3 & 246.8 \\
\hline 005 Woodstock & 137.7 & 147.7 & 239.0 & 404.0 & 360.3 & 577.0 & 782.3 \\
\hline 006 Westbrook & 186.0 & 280.7 & 154.7 & 184.7 & 134.0 & 256.3 & 211.7 \\
\hline 007 Willimantic & 90.5 & 78.8 & 106.5 & 132.5 & 222.3 & 304.5 & 307.0 \\
\hline 008 Woodbury & 6.0 & 9.0 & 32.8 & 9.0 & 32.8 & 106.5 & 58.8 \\
\hline 009 Sherman & 41.5 & 87.3 & 130.3 & 457.0 & 236.8 & 532.3 & 427.3 \\
\hline 010 Greenwich & 45.8 & 63.5 & 72.8 & 173.8 & 103.3 & 196.8 & 97.3 \\
\hline 012 Warren & 8.0 & 8.0 & 24.3 & 62.3 & 78.7 & 165.3 & 118.0 \\
\hline 014 Mid Haddam & 357.3 & 461.7 & 454.0 & 233.3 & 196.7 & 422.3 & 310.7 \\
\hline 015 Southington & 6.4 & 9.6 & 13.4 & 14.6 & 16.6 & 21.2 & 7.8 \\
\hline 102 New Hartford & 16.5 & 3.0 & 3.5 & 23.8 & 3.0 & 23.3 & 17.8 \\
\hline 116 Granby & 2.8 & 8.5 & 2.8 & 0.0 & 2.8 & 10.8 & 13.8 \\
\hline Mean & 89.81 & 120.96 & 126.10 & 163.62 & 136.11 & 251.84 & 219.39 \\
\hline SD & 101.64 & 138.93 & 131.99 & 145.95 & 106.26 & 185.33 & 208.57 \\
\hline
\end{tabular}

\begin{tabular}{|l|l|l|l|l|l|l|l|}
\hline Routes & 1998 & 1999 & 2000 & 2001 & 2002 & Mean & SD \\
\hline 001 Mystic & 203.5 & 168.8 & 157.8 & 151.8 & 274.8 & 140.10 & 69.04 \\
\hline 003 Buckingham & 380.0 & 257.0 & 233.0 & 202.8 & 311.3 & 273.73 & 64.85 \\
\hline 004 Uncasville & 421.5 & 185.0 & 241.3 & 254.5 & 307.0 & 246.08 & 89.66 \\
\hline 005 Woodstock & 676.3 & 632.7 & 610.7 & 596.0 & 727.0 & 490.89 & 225.35 \\
\hline 006 Westbrook & 282.0 & 229.3 & 192.7 & 170.0 & 174.3 & 204.69 & 48.23 \\
\hline 007 Willimantic & 393.5 & 230.0 & 275.5 & 306.5 & 337.5 & 232.08 & 106.51 \\
\hline 008 Woodbury & 182.0 & 238.8 & 361.3 & 243.3 & 523.8 & 150.31 & 165.18 \\
\hline 009 Sherman & 725.5 & 759.8 & 745.5 & 549.5 & 1197.8 & 490.85 & 338.67 \\
\hline 010 Greenwich & 169.3 & 253.8 & 246.8 & 172.8 & 227.0 & 151.88 & 73.20 \\
\hline 012 Warren & 256.0 & 356.0 & 484.0 & 406.3 & 557.7 & 210.39 & 196.22 \\
\hline 014 Mid Haddam & 318.7 & 200.3 & 201.0 & 136.0 & 155.7 & 287.31 & 116.47 \\
\hline 015 Southington & 28.2 & 27.8 & 43.0 & 60.2 & 50.2 & $\underline{24.92}$ & 17.64 \\
\hline 102 New Hartford & 46.3 & 49.0 & 116.0 & 104.5 & 141.8 & 45.69 & 48.32 \\
\hline 116 Granby & 13.8 & 56.0 & 55.0 & 86.8 & 88.0 & $\underline{28.40}$ & 33.50 \\
\hline Mean & 292.60 & 260.30 & 283.10 & 245.77 & $\underline{362.40}$ & & \\
\hline SD & 217.50 & 207.13 & 204.08 & 165.94 & 307.19 & & \\
\hline
\end{tabular}

Table 4. Summary of linear regression results of Lyme disease rate on two measures of annual weather conditions

\begin{tabular}{llllccc}
\hline & \multicolumn{3}{c}{ Annual DPNP $^{\mathbf{a}}$} & \multicolumn{3}{c}{ Annual DPNT $^{\mathbf{b}}$} \\
\cline { 2 - 7 } Routes & $\mathrm{b} 1$ & $\mathrm{r}^{2}$ & $\mathrm{P}$ & $\mathrm{b} 1$ & $\mathrm{r}^{2}$ & $\mathrm{P}$ \\
\hline 001 Mystic & -8.42 & 0.18 & 0.48 & 35.45 & 0.38 & 0.11 \\
003 Buckingham & & & N/A & & & N/A \\
004 Uncasville & 10.09 & 0.58 & 0.04 & 20.09 & 0.05 & 0.56 \\
005 Woodstock & 7.58 & 0.09 & 0.69 & & & $\mathrm{~A} / \mathrm{N}$ \\
006 Westbrook & & & N/A & -3.01 & 0.02 & 0.84 \\
007 Willimantic & & & N/A & & & N/A \\
008 Woodbury & 0.89 & 0.004 & 0.88 & 8.71 & 0.35 & 0.59 \\
009 Sherman & 107.84 & 0.73 & 0.03 & 127.08 & 0.48 & 0.19 \\
010 Greenwich & 4.37 & 0.11 & 0.53 & 1.72 & 0.002 & 0.93 \\
012 Warren & & & N/A & 39.56 & 0.99 & 0.07 \\
014 Mid Haddam & 11.39 & 0.51 & 0.18 & -0.21 & 0.000 & 0.99 \\
015Southington & -0.15 & 0.003 & 0.95 & 1.23 & 0.03 & 0.73 \\
102 New Hartford & -8.35 & 0.36 & 0.29 & 0.46 & 0.000 & 0.97 \\
116 Granby & -3.08 & 0.34 & 0.06 & 4.53 & 0.03 & 0.60 \\
\hline
\end{tabular}

${ }^{a}$ DPNP, departure from normal precipitation in inches. ${ }^{b}$ DPNT, departure from normal temperature in degrees Fahrenheit. N/A, no data available. 
Table 5. Summary of linear regression results for number of birds observed versus departure from normal June precipitation data. Table-wide alpha level for statistical significance was $\mathrm{P}<0.004$ after sequential Bonferroni correction

\begin{tabular}{lllllllllllllll}
\hline & \multicolumn{1}{c}{ SCLP $^{1}$} & \multicolumn{4}{c}{ American Robin } & \multicolumn{3}{c}{ Gray Catbird } & \multicolumn{3}{c}{ American Redstart } \\
\hline Routes & $\mathrm{b} 1$ & $\mathrm{r}^{2}$ & $\mathrm{P}$ & $\mathrm{b} 1$ & $\mathrm{r}^{2}$ & $\mathrm{P}$ & $\mathrm{b} 1$ & $\mathrm{r}^{2}$ & $\mathrm{P}$ & $\mathrm{b} 1$ & $\mathrm{r}^{2}$ & $\mathrm{P}$ \\
\hline Mystic *001 & 0.47 & 0.002 & 00.9 & 1.27 & 0.05 & 0.49 & 1.16 & 0.15 & 0.24 & $0.20-$ & 0.08 & 0.39 \\
003 Buckingham & 1.58 & 0.04 & 0.59 & 0.48 & 20.0 & 0.73 & -0.37 & 0.02 & 0.68 & 0.34 & 0.08 & 0.42 \\
004 Uncasville & $0.48-$ & 0.03 & 0.76 & -0.32 & 0.02 & 0.78 & -0.96 & 0.43 & 0.16 & 0.25 & 0.04 & 0.70 \\
*005 Woodstock & -1.34 & 0.01 & 0.85 & 0.24 & 0.01 & 0.89 & 1.15 & 0.08 & 0.59 & 0.59 & 0.10 & 0.54 \\
006 Westbrook & 8.65 & 0.03 & 0.83 & -0.42 & 0.001 & 0.98 & 5.23 & 0.26 & 0.49 & $0.12-$ & 0.05 & 0.78 \\
007 Willimantic & $1.39-$ & 0.01 & 0.79 & $1.52-$ & 0.13 & 0.30 & 1.44 & 0.08 & 0.44 & $0.66-$ & 0.33 & 0.09 \\
008 Woodbury & 19.21 & 0.09 & 0.35 & $0.16-$ & 0.000 & 0.96 & 6.21 & 0.13 & 0.25 & 0.44 & 0.03 & 0.60 \\
Sherman *009 & 1.12 & 0.02 & 0.70 & -1.67 & 0.16 & 0.25 & 0.06 & 0.001 & 0.94 & 0.6 & 0.11 & 0.34 \\
010 Greenwich & 0.95 & 0.01 & 0.82 & 0.22 & 0.004 & 0.88 & 0.57 & 0.02 & 0.71 & $0.02-$ & 0.002 & 0.90 \\
012 Warren & -5.66 & 0.33 & 0.24 & -0.76 & 0.09 & 0.57 & -0.49 & 0.05 & 0.66 & 1.34 & 0.22 & 0.35 \\
*014 Mid Haddam & 4.45 & 0.57 & 0.08 & 1.38 & 0.05 & 0.66 & -0.17 & 0.02 & 0.77 & 0.29 & 0.05 & 0.67 \\
015 Southington & -0.17 & 0.001 & 0.94 & -1.89 & 0.25 & 0.12 & -0.02 & 0.000 & 0.97 & $0.07-$ & 0.04 & 0.58 \\
*102 New Hartford & -4.04 & 0.40 & 0.07 & 2.09 & 0.07 & 0.45 & 0.01 & 0.000 & 0.99 & 0.25 & 0.02 & 0.74 \\
Granby *116 & 2.56 & 0.07 & 0.62 & -0.70 & 0.17 & 0.42 & -1.21 & 0.11 & 0.53 & 0.85 & 0.73 & 0.03 \\
\hline
\end{tabular}

* Route had one observer for all years. ${ }^{1}$ SCLP: Species carrying Lyme pathogen.

Table 6. Summary of linear regression results for number of birds observed versus departure from normal June temperature DPNT. Table-wide alpha level for statistical significance was $\mathrm{P}<0.004$ after sequential Bonferroni correction

\begin{tabular}{lllllllllllllll}
\hline \multirow{2}{*}{ Routes } & \multicolumn{4}{l}{ SCLP $^{\mathrm{a}}$} & \multicolumn{4}{c}{ American Robin } & \multicolumn{3}{c}{ Gray Catbird } & \multicolumn{4}{c}{ American Redstart } \\
\cline { 2 - 13 } & $\mathrm{b} 1$ & $\mathrm{r}^{2}$ & $\mathrm{P}$ & $\mathrm{b} 1$ & $\mathrm{r}^{2}$ & $\mathrm{P}$ & $\mathrm{b} 1$ & $\mathrm{r}^{2}$ & $\mathrm{P}$ & $\mathrm{b} 1$ & $\mathrm{r}^{2}$ & $\mathrm{P}$ \\
\hline Mystic *001 & -4.35 & 0.05 & 0.54 & $2.53-$ & 0.07 & 0.45 & -1.40 & 0.06 & 0.47 & 0.34 & 0.07 & 0.47 \\
003 Buckingham & -1.90 & 0.03 & 0.62 & $1.09-$ & 0.05 & 0.54 & 0.25 & 0.007 & 0.82 & $1.05-$ & 0.47 & 0.03 \\
004 Uncasville & 3.85 & 0.17 & 0.42 & 1.78 & 0.07 & 0.61 & 3.66 & 00.6 & 0.07 & $1.41-$ & 20.1 & 0.49 \\
*005 Woodstock & 0.01 & 0.000 & 0.99 & 1.80 & 20.3 & 0.24 & 0.39 & 0.01 & 0.85 & $0.02-$ & 0.000 & 0.98 \\
006 Westbrook & -11.02 & 0.22 & 0.54 & $4.22-$ & 0.30 & 0.46 & 4.92 & 10.8 & 0.09 & 0.04 & 0.02 & 0.86 \\
007 Willimantic & -0.03 & 0.000 & 0.99 & 1.90 & 20.1 & 0.32 & $1.93-$ & 0.08 & 0.43 & 0.54 & 30.1 & 00.3 \\
008 Woodbury & 1.67 & 0.01 & 0.87 & 2.14 & 0.16 & 0.51 & $0.12-$ & 0.002 & 0.94 & 1.27 & 0.45 & 0.22 \\
Sherman *009 & 4.88 & 0.07 & 0.56 & 2.62 & 0.05 & 0.62 & 0.45 & 0.01 & 0.82 & -1.86 & 0.16 & 0.38 \\
010 Greenwich & -6.79 & 0.12 & 0.45 & $1.70-$ & 00.1 & 0.51 & $0-3.4$ & 30.3 & 0.18 & 0.16 & 00.1 & 0.50 \\
012 Warren & 2.32 & 0.03 & 0.80 & $2.32-$ & 00.3 & 0.34 & -0.68 & 0.03 & 0.76 & 3.01 & 20.5 & 0.17 \\
*014 Mid Haddam & -0.92 & 0.01 & 0.90 & -1.60 & 10.0 & 0.82 & $0-1.2$ & 10.2 & 0.35 & 2.00 & 0.46 & 0.14 \\
015 Southington & 5.24 & 0.25 & 0.21 & 2.47 & 00.2 & 0.17 & -0.52 & 0.04 & 0.63 & -0.17 & 0.09 & 0.47 \\
*102 New Hartford & 0.85 & 0.01 & 0.76 & $0.74-$ & 0.05 & 00.6 & 0.19 & 0.01 & 0.79 & -0.19 & 0.006 & 0.85 \\
Granby *116 & -0.51 & 0.002 & 0.93 & 4.69 & 01.0 & 0.08 & 0.43 & 0.01 & 0.83 & -0.36 & 0.12 & 0.49 \\
\hline
\end{tabular}

* Route had one observer for all years. ${ }^{a}$ SCLP: Species carrying Lyme pathogen.

Species Carrying Lyme Pathogen (SCLP): After using Bonferroni correction for multiple tests, the study found that only 008 Woodbury and 012 Warren had a statistically significant relationship between the number of birds observed from species carrying the Lyme pathogen and Lyme disease rate. All other routes had no statistically significant relationship between the number of birds observed and Lyme disease rate because $\mathrm{P}$ values for them were greater than 0.05 .

American Robin: after using Bonferroni correction for multiple tests, the study found that only 012 Warren had a statistically significant relationship between the number of birds observed and Lyme disease rate. All other routes had no statistically significant relationship between the number of birds observed and Lyme disease rate because $\mathrm{P}$ values for them were greater than 0.05 .

Gray Catbird: after using Bonferroni correction for multiple tests, the study found that only 008 Woodbury, 009 Sherman and 012 Warren had statistically significant positive relationships between Gray Catbird number and 
Lyme disease rate. After Bonferroni correction for multiple tests, only 102 New Hartford still had a statistically significant negative relationship between the number of Gray Catbirds observed and Lyme disease rate. All other routes had no statistically significant relationship between number of birds and Lyme disease rate because $\mathrm{P}$ values for them were greater than 0.05 .

American Redstart: after using Bonferroni correction for multiple tests, (008 Woodbury and 012 Warren). All other routes had no statistically significant relationship between the number of birds and Lyme disease rate because $\mathrm{P}$ values for them were greater than 0.05 .

The study tried to find a logical or evident explanation for the result from these two routes, or the study needed to get an answer for the question: Is there a relationship between the result for these two routes and the observer identities? The study found that there were two observers for these two routes, but it was not an evident explanation because other routes also had more than one observer over years (1991-2002) and these routes did not show a positive relationship between the number of birds observed and Lyme disease rate

The study noticed that Gray Catbird group was the only group that had three statistically significant positive relationships between the number of birds observed and Lyme disease rate (008 Woodbury, 009 Sherman, and 012 Warren). The study found that appearance of positive relationship is related to the Gray Catbird's behavior. The Gray Catbird lives in dense shrubs between thickets of young trees, and nests at the center of dense shrubs, small trees, or in vines (Cornell Laboratory of Ornithology n.d.). Therefore, it will be in contact with the black-legged tick (Ixodes scapularis) that lives in forests with rich and moist undergrowth. Also, the tick's larva has a high molting success on Gray Catbirds (Brunner et al., 2011).

The American Redstart was my control species because this species may not be able to support the pathogen because at least two tick larvae were tested and were not infected with the pathogen (Brinkerhoff et al. 2011). However, the study found that there was a positive relationship between the number of American Redstarts observed and Lyme disease rate for 008 Woodbury and 012 Warren. Therefore, the result does not support this prediction and thus it does not support my hypothesis.

The Connecticut land use map (Figure 6) does not show an evident difference between the routes that had statistically significant positive relationships between the number of birds observed and Lyme disease rate (routes 008 Woodbury, 009 Sherman, and 012 Warren) and other routes. In other words, based on the geography that the Connecticut land use map shows, the study did not find obvious geographical differences between the routes that had statistically significant positive relationships between the number of birds observed and Lyme disease rate (routes 008 Woodbury, 009 Sherman, and 012 Warren) and other routes

There was no difference between the routes that had statistically significant positive relationships between the number of birds observed and Lyme disease rate (routes 008 Woodbury, 009 Sherman, and 012 Warren) and other routes (Figure 7). The study found that the low population sizes for these three routes' towns $(693-10,807)$ was the same as that for routes 003 Buckingham and 005 Woodstock, two routes that had no significant relationship between the number of birds observed and Lyme disease rate.

From all the results that the study found in this research, the study rejected the hypothesis because there is no strong relationship between the number of birds that could be infected with B. burgdorferi and the rate of Lyme disease in people. Therefore, birds do not appear to play an important role for transmitting Lyme disease to people, at least using the methods I used here.

\section{Suggestions}

The study suggests to use another method by studying other individual bird species separately like the study did for American Robin, Gray Catbird and American Redstart, or to use other species as control species. Future studies should also verify that American Redstarts do not carry the Lyme disease pathogen. Researchers could also choose another state that has a high Lyme disease rate, such as New Jersey or Wisconsin, to try to repeat my findings. Another suggestion is to make a new study for the bird species the researcher used but using a different range of years, such as using the last five or ten years. Finally, because Lyme disease can affect dogs and horses (Carmel \& Edwards, 1989), the study suggests that it would be interesting to study the relationship between the rate of Lyme disease in these domestic animals and the numbers of birds from species known to carry the Lyme disease pathogen. 
Table 7. Summary of linear regression results for number of birds observed on Connecticut Breeding Bird Survey routes versus Lyme disease rate for 1991-2002. Bold italics indicate statistically significant relationship after sequential Bonferroni correction

\begin{tabular}{|c|c|c|c|c|c|c|c|c|c|c|c|c|}
\hline \multirow[t]{2}{*}{ Routes } & \multicolumn{3}{|c|}{$\mathrm{SCLP}^{\mathrm{a}}$} & \multicolumn{3}{|c|}{ American Robin } & \multicolumn{3}{|c|}{ Gray Catbird } & \multicolumn{3}{|c|}{ American Redstart } \\
\hline & b1 & $r^{2}$ & $\mathrm{P}$ & b1 & $r^{2}$ & $\mathrm{P}$ & b1 & $r^{2}$ & $\mathrm{P}$ & b1 & $r^{2}$ & $\mathrm{P}$ \\
\hline Mystic *001 & 1.29 & 0.26 & 0.09 & 3.57 & 0.48 & 0.01 & 1.42 & 0.02 & 0.64 & -20.22 & 0.28 & 0.08 \\
\hline 003 Buckingham & 0.38 & 0.01 & 0.73 & 1.14 & 0.02 & 0.67 & 3.42 & 0.11 & 0.29 & 7.29 & 0.08 & 0.38 \\
\hline 004 Uncasville & -1.99 & 0.33 & 0.14 & -3.22 & 0.19 & 0.28 & -7.02 & 0.39 & 0.04 & -3.79 & 0.07 & 0.53 \\
\hline *005 Woodstock & 2.69 & 0.12 & 0.50 & -8.00 & 0.07 & 0.62 & 18.76 & 0.57 & 0.08 & -16.87 & 0.09 & 0.55 \\
\hline 006 Westbrook & -0.92 & 0.46 & 0.14 & -2.39 & 0.39 & 0.18 & $2.64-$ & 0.19 & 0.39 & 20.67 & 0.04 & 0.70 \\
\hline 007 Willimantic & 1.97 & 0.41 & 0.03 & 5.34 & 0.29 & 0.07 & 5.91 & 0.45 & 0.02 & 8.71- & 0.04 & 0.53 \\
\hline 008 Woodbury & 0.93 & 0.72 & $<0.001$ & 5.07 & 0.49 & 0.01 & 3.59 & 0.77 & $<0.001$ & 24.51 & 0.79 & $<0.001$ \\
\hline Sherman *009 & -0.89 & 0.004 & 0.85 & -17.94 & 0.38 & 0.03 & 31.18 & 0.57 & 0.004 & 27.13 & 0.15 & 0.21 \\
\hline 010 Greenwich & 0.61 & 0.04 & 0.57 & -1.33 & 0.02 & 0.69 & 3.28 & 0.17 & 0.24 & -53.02 & 0.33 & 0.08 \\
\hline 012 Warren & 1.14 & 0.78 & $<0.001$ & 8.37 & 0.82 & 0.001 & 5.59 & 00.8 & $<0.001$ & 17.74 & 0.71 & 0.001 \\
\hline *014 Mid Haddam & 2.35 & 0.27 & 0.29 & 0.16 & 0.001 & 0.95 & 11.17 & 0.22 & 0.34 & 6.61 & 00.1 & 0.54 \\
\hline 015 Southington & -0.43 & 0.26 & 0.11 & -0.14 & 0.005 & 0.84 & 0.25 & 0.01 & 0.83 & -4.87 & 0.11 & 0.32 \\
\hline *102 New Hartford & -2.58 & 0.68 & 0.01 & -2.89 & 0.18 & 0.25 & -11.37 & 0.79 & 0.001 & -4.56 & 0.19 & 0.24 \\
\hline Granby *116 & -0.06 & 0.06 & 0.66 & -0.23 & 0.101 & 0.54 & $0.14-$ & 0.05 & 0.69 & 0.36 & 0.02 & 0.78 \\
\hline
\end{tabular}

* Route had one observer for all years. ${ }^{a}$ SCLP: Species carrying Lyme pathogen

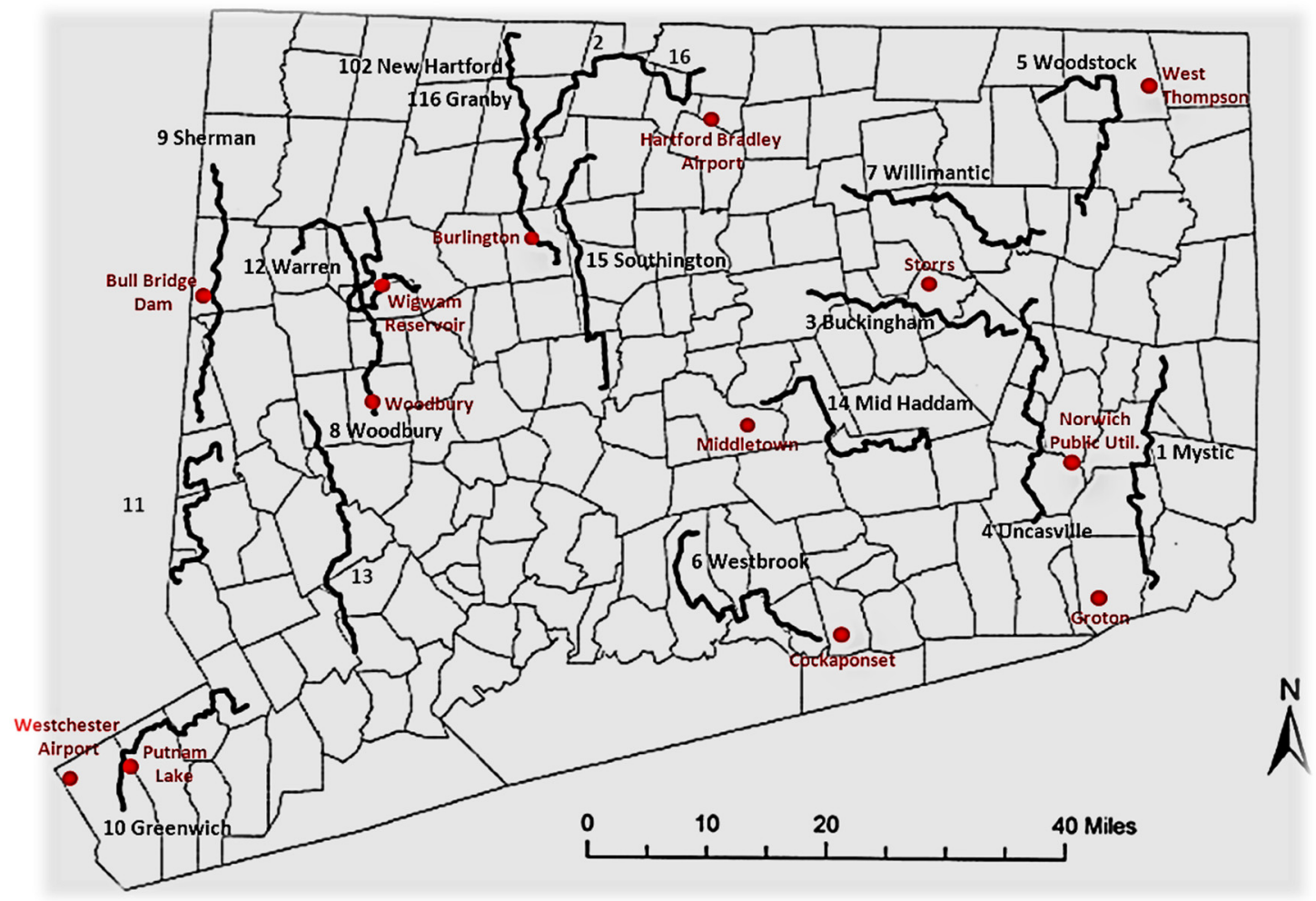

Figure 1. Connecticut Breeding Bird Survey routes and NOAA weather stations used in this study. The black words indicate the routes. The red words indicate the weather stations. Blue letters indicate routes not used in this study because they were not active routes 

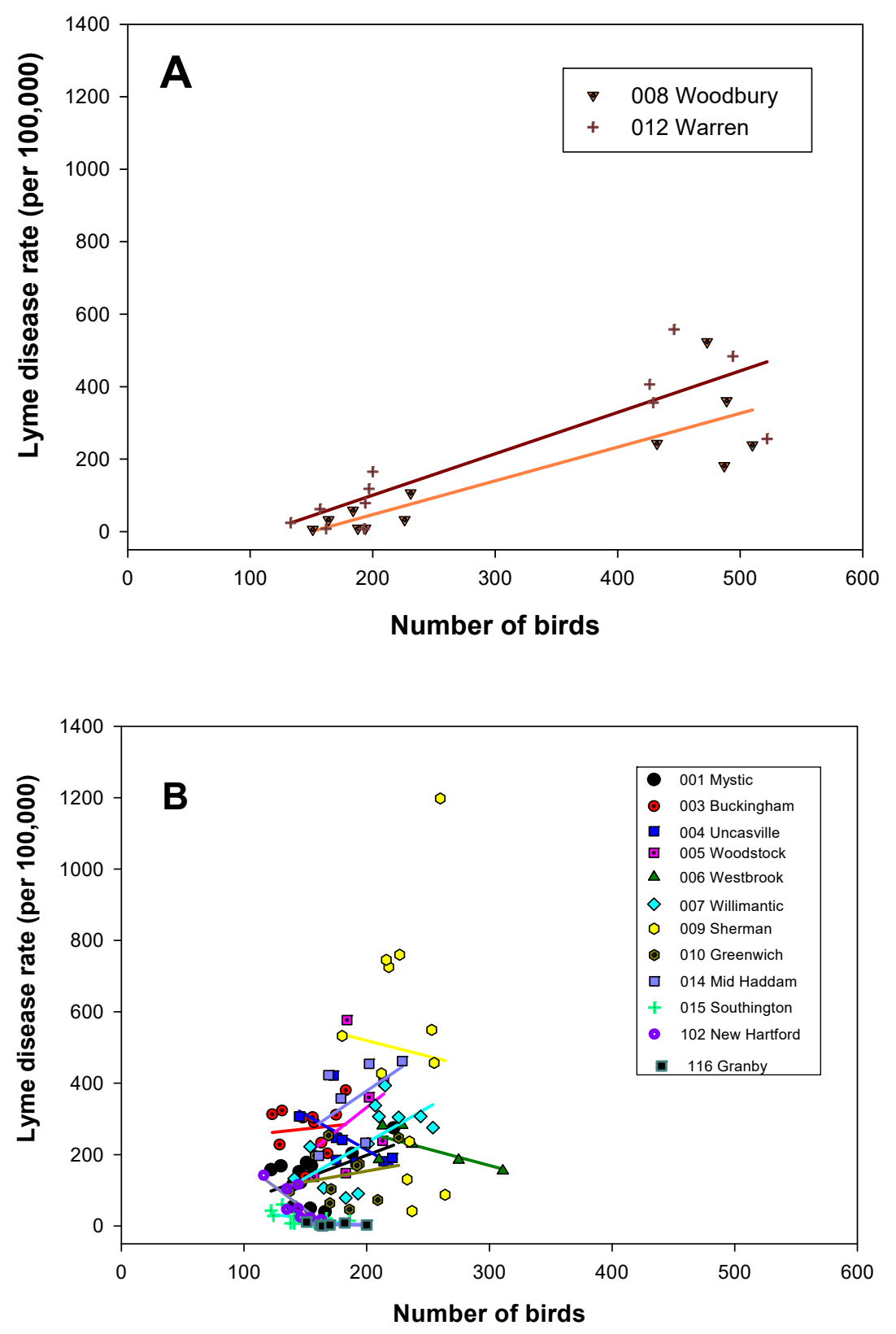

Figure 2. Relationship between numbers of birds counted from species carrying Lyme pathogen and the rate of Lyme disease for Connecticut Breeding Bird Survey routes from 1991 -2002. A) Routes for which this relationship was statistically significant positive after sequential Bonferroni correction. B) Routes for which this relationship was not statistically significant after sequential Bonferroni correction 

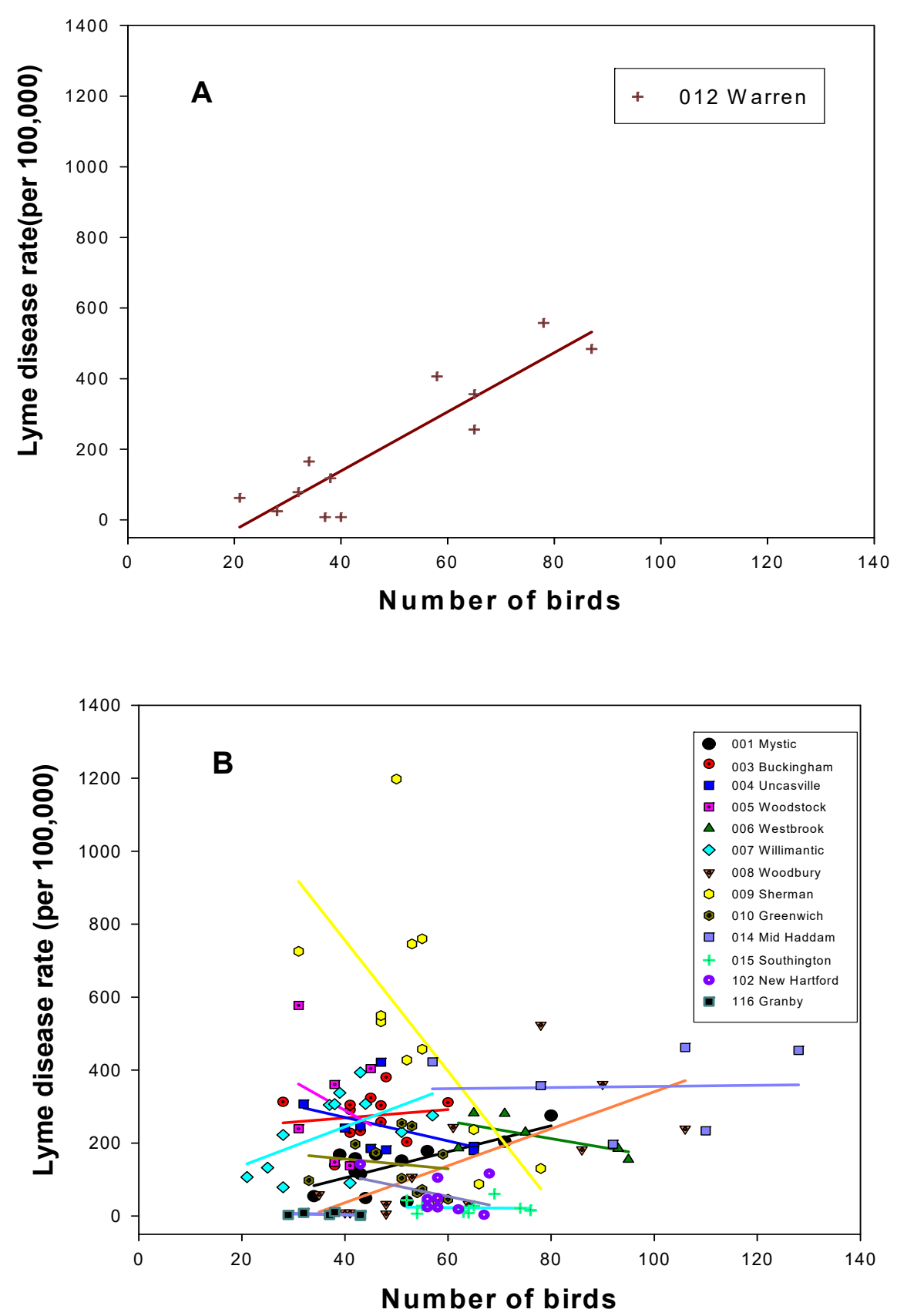

Figure 3. Relationship between number of American Robin and the rate of Lyme disease for Connecticut Breeding Bird Survey routes from 1991 -2002. A) Routes for which this relationship was statistically significant positive after sequential Bonferroni correction. B) Routes for which this relationship was not statistically significant after sequential Bonferroni correction 

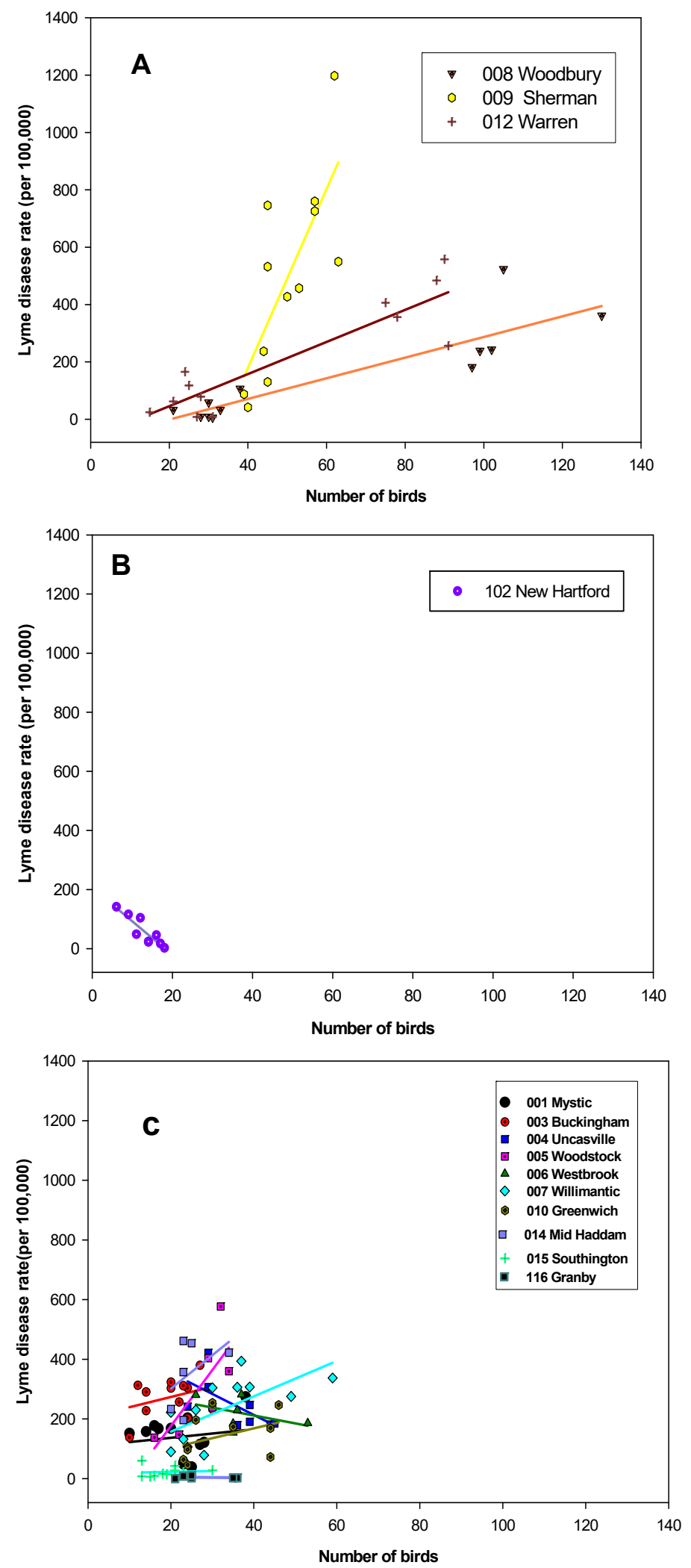

Figure 4. Relationship between number of Gray Catbirds and the rate of Lyme disease for Connecticut Breeding Bird Survey routes from 1991-2002. A) Routes for which this relationship was statistically significant positive after sequential Bonferroni correction. B) Routes for which this relationship was statistically significant negative after sequential Bonferroni correction. C) Routes for which this relationship was not statistically significant after sequential Bonferroni correction 

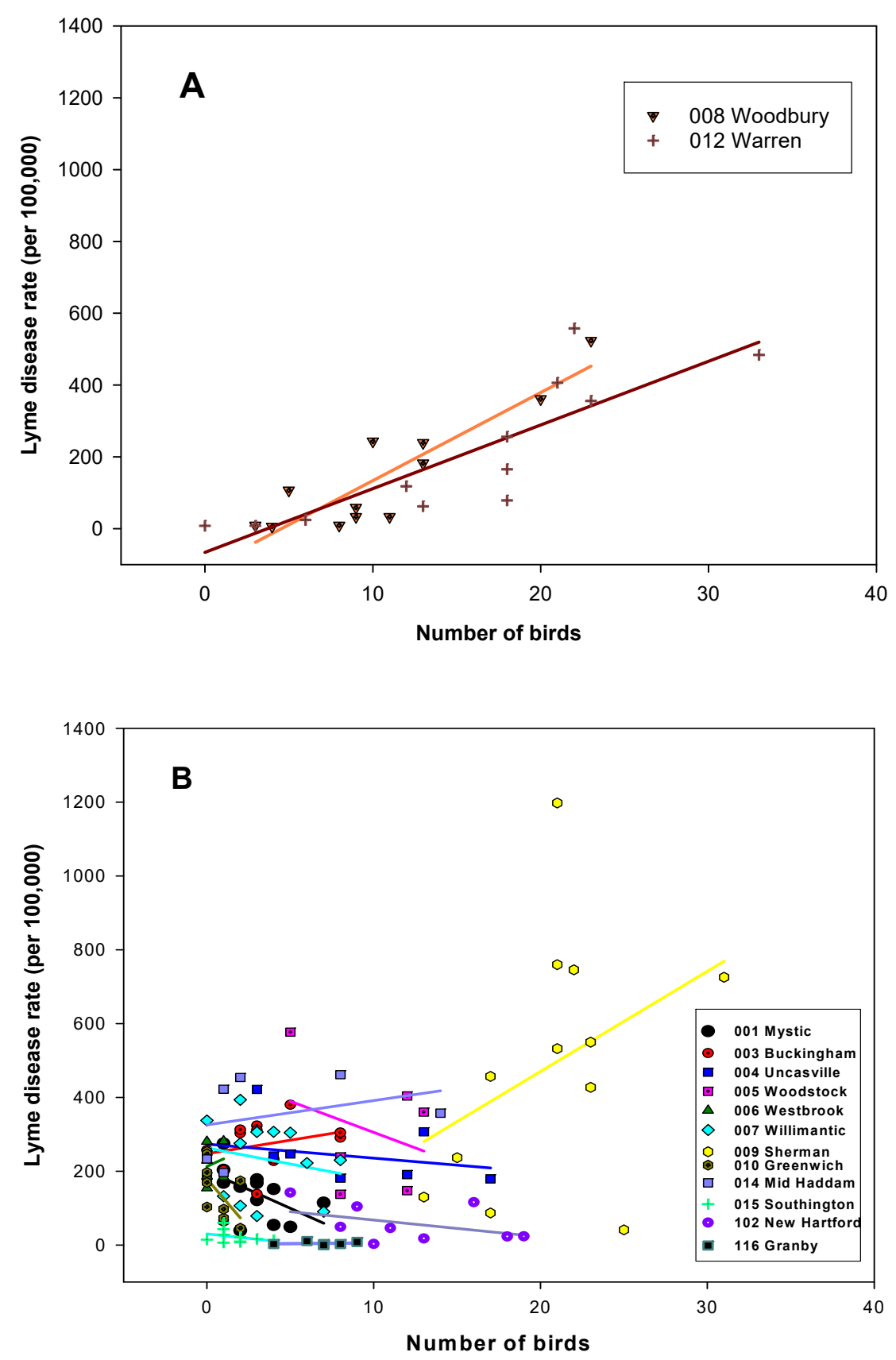

Figure 5. Relationship between number of American Redstarts and the rate of Lyme disease for Connecticut Breeding Bird Survey routes from 1991-2002. A) Routes for which this relationship was statistically significant positive after sequential Bonferroni correction. B) Routes for which this relationship was not statistically significant after sequential Bonferroni correction 


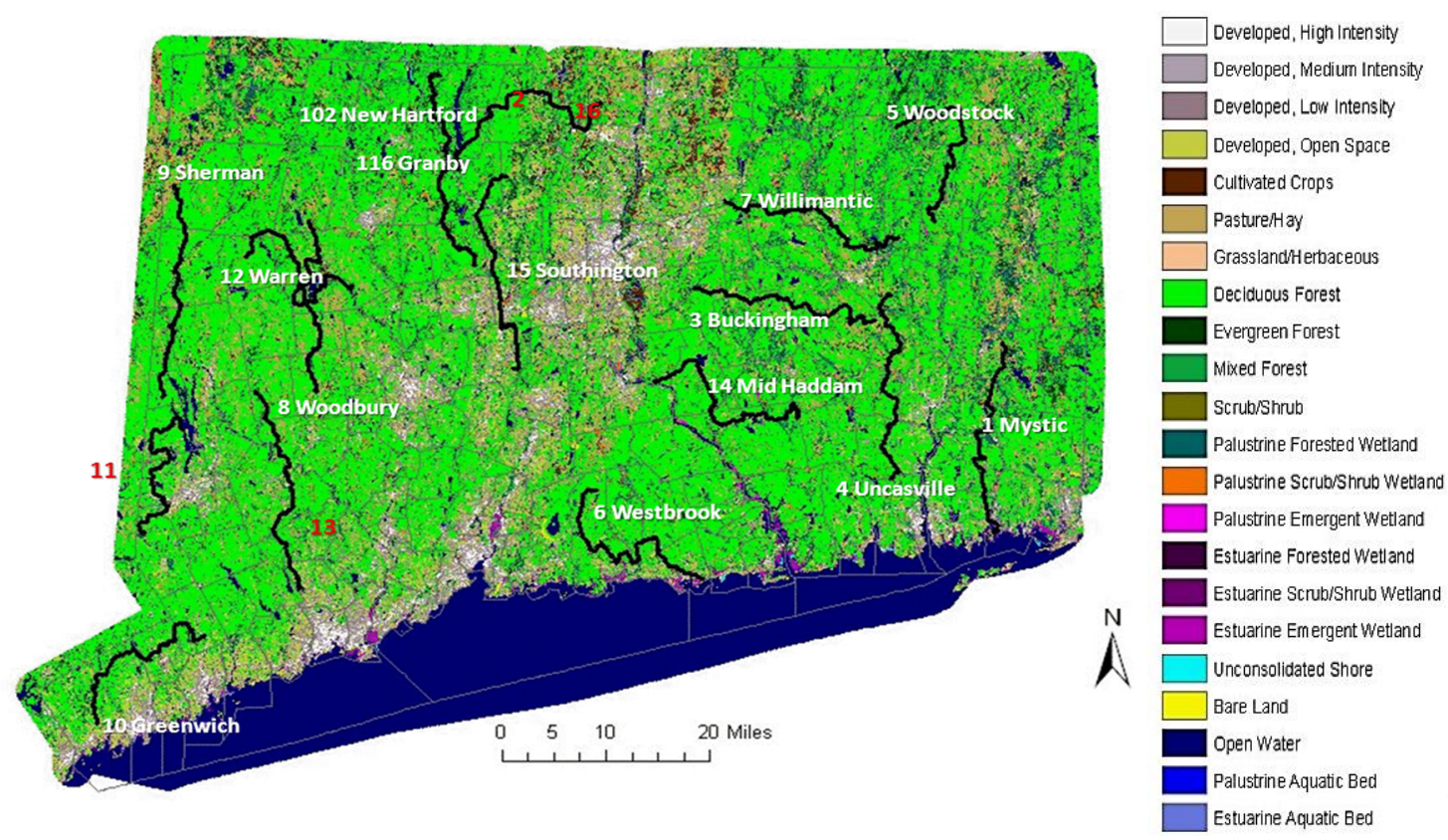

Figure 6. Connecticut Breeding Bird Survey routes and land use in 2001. Land use data are from http://www.csc.noaa.gov/crs/lca/northeast.html. Routes with red numbers indicate routes not used in this study because they were not active routes

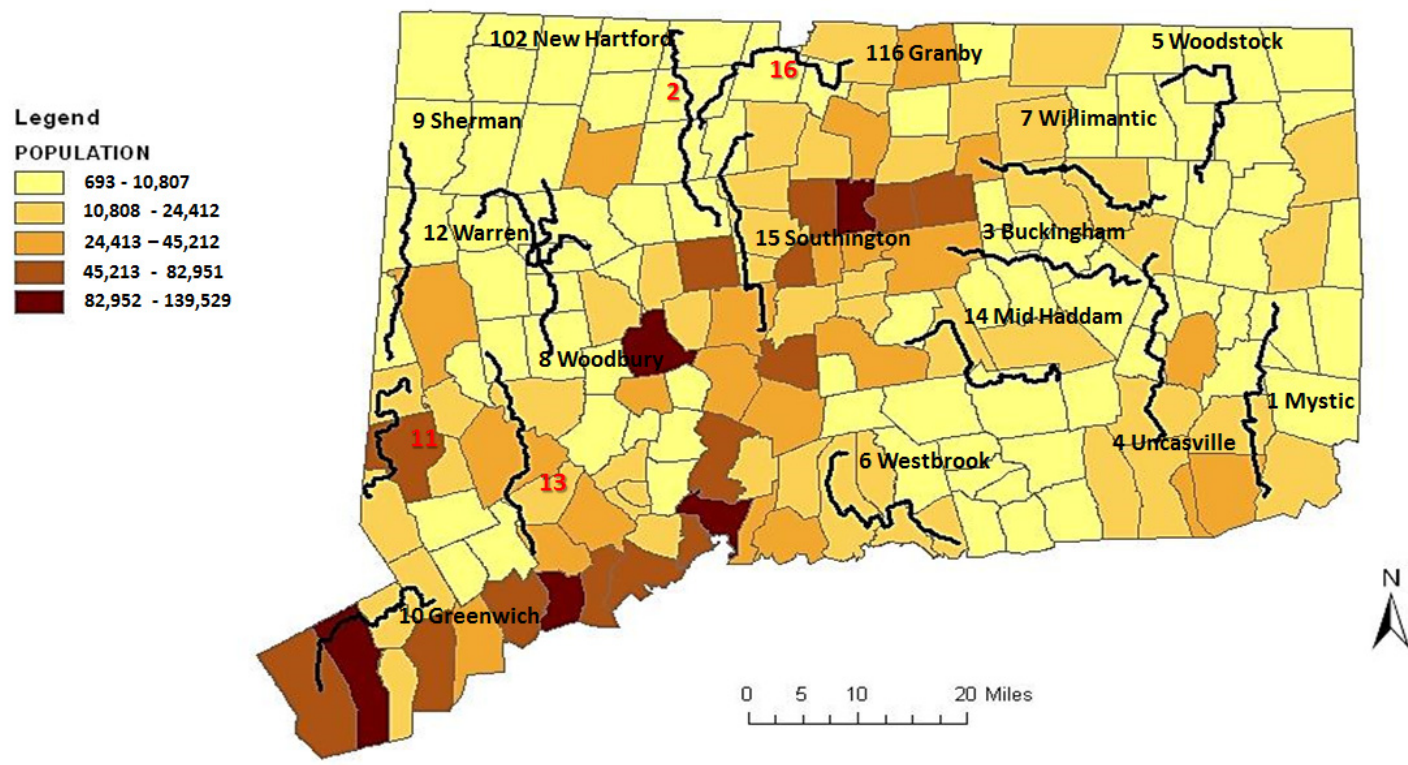

Figure 7. Connecticut Breeding Bird Survey routes and population size of Connecticut towns from the 2000 U.S. federal census. Census data are from http://factfinder2.census.gov using the file "Total Population (P001) - 2000 SF1 100\% data". Colors represent groupings as determined by the Jenks Natural Breaks method. Routes with red numbers indicate routes not used in this study because they were not active routes

\section{References}

American College of Rheumatology. (2011). Lyme disease. Retrieved May 23, 2012, from http://www.rheumatology.org/practice/clinical/patients/diseases_and_conditions/lymedisease.pdf

American Lyme disease Foundation. (2010). Lyme disease. Retrieved May 20, 2012, from http://www.aldf.com/ lyme.shtml 
American Pest. (2011). Pest Identification/Ticks. Retrieved May 22, 2011, from http://www.americanpest.net/ pest-identification/profile/ticks

Anguita, J., Hedrick, M. N., \& Fikrig, E. (2003). Adaptation of Borrelia burgdorferi in the tick and the mammalian host. FEMS microbiology reviews, 27(4), 493-504. http://dx.doi.org/10.1016/S0168-6445 (03)00036-6

Bhate, C., \& Schwartz, R. A. (2011). Lyme disease: Part I. Advances and perspectives. Journal of the American Academy of Dermatology, 64(4), 619-636. http://dx.doi.org/10.1016/j.jaad.2010.03.016

Brinkerhoff, R. J., Folsom-O'Keefe, C. M., Tsao, K., \& Diuk-Wasser, M. A. (2011). Do birds affect Lyme disease risk? Range expansion of the vector-borne pathogen Borrelia burgdorferi. Frontiers in Ecology and the Environment, 9(2), 103-110. http://dx.doi.org/10.189/090062

Brunner, J. L., Cheney, L., Keesing, F., Killilea, M., Logiudice, K., Previtali, A., \& Ostfeld, R. S. (2011). Molting success of Ixodes scapularis varies among individual blood meal hosts and species. Journal of medical entomology, 48(4), 860-866. http://dx.doi.org/10.1603/ME10256

Burgdorfer, W., Barbour, A. G., Hayes, S. F., Benach, J. L., Grunwaldt, E., \& Davis, J. P. (1982). Lyme disease-a tick-borne spirochetosis?. Science, 216(4552), 1317-1319.

California Department of Health Services. (2005). West Nile Virus Study Guide. Retrieved from westnile.ca.gov/website/edu_materials/West\%20Nile\%20Study\%20Guide\%203-6-2006.pdf

Carmel DK and Edwards GH. (1989). Lyme disease in animals. Maryland Cooperative Extension Fact Sheet. Retrieved May 28, 2012, from http://extension.umd.edu/publications/pdfs/fs534.pdf

Center for Integration of Natural Disaster Information. (2001). West Nile Virus Maps. Retrieved May 27, 2012, from http://diseasemaps.usgs.gov/2001/

Centers for Disease Control and Prevention (CDC). (2007). Lyme disease--United States, 2003-2005. Morbidity and Mortality Weekly Report, 56(23), 573-576.

Centers for Disease Control and Prevention. (2007). Tick Management Handbook. Retrieved May 25, 2012, from http://www.cdc.gov/ncidod/dvbid/lyme/resources/handbook.pdf

Centers for Disease Control and Prevention. (2011). Lyme disease/ Lyme disease statistics. Retrieved May 25, 2012, from http://www.cdc.gov/lyme/stats/chartstables/incidencebystate.html

Centers for Disease Control and Prevention. (2011). Lyme disease/Lyme Disease Diagnosis and Treatment. Retrieved June 10, 2012, from http://www.cdc.gov/lyme/diagnosistreatment/Treatment/

Centers for Disease Control and Prevention. (n.d.). Lyme disease: A Public Information Guide. Retrieved May 25, 2012, from www.cdc.gov/lyme/resources/brochure/508_LD_Brochure.pdf

Connecticut Department of Public Health. (2008). A brief history of Lyme disease in Connecticut. Retrieved May 25, 2012, from http://www.ct.gov/dph/cwp/view.asp?a=3136\&q=388506

Connecticut Department of Public Health. (2011). Lyme disease cases and rate by town and county. Retrieved May 25, 2012, from www.ct.gov/dph/cwp/view.asp?a=3136\&Q=399694\&dphPNavCtr=|\#46999

Cornell Laboratory of Ornithology. (n.d.) All About Birds website. Gray Catbird. Retrieved May 14, 2012, from http://www.allaboutbirds.org/guide/Gray_Catbird/lifehistory

Cornell Laboratory of Ornithology. (n.d.). All About Birds website. American Robin. Retrieved May 14, 2012, from http://www.allaboutbirds.org/guide/American_robin/id\#at_nesting

Cornell Laboratory of Ornithology. (n.d.). All About Birds website. American Robin. Retrieved May 25, 2012, from http://www.allaboutbirds.org/guide/American_robin/lifehistory\#at_nesting

Cornell University, Department of Entomology. (2012). Integrated Pest Management for the Deer Tick. Retrieved September 17, 2012, from http://counties.cce.cornell.edu/warren/Deer-Tick.pdf

Fall, A. G., Diaite, A., Etter, E., Bouyer, J., Ndiaye, T. D., \& Konaté, L. (2012). The mosquito Aedes (Aedimorphus) vexans arabiensis as a probable vector bridging the West Nile virus between birds and horses in Barkedji (Ferlo, Senegal). Medical and veterinary entomology, 26(1), 106-111. doi: 10.1111/j.1365-2915.2011.00974.x

Johnson, L. (n.d.). Borellia burgdorferi - Fact Sheet. Retrieved June 2, 2012, from http://www.lymedisease.org/pdf/Bbfacts.pdf 
Johnson, R. C., Schmid, G. P., Hyde, F. W., Steigerwalt, A. G., \& Brenner, D. J. (1984). Borrelia burgdorferi sp. nov.: etiologic agent of Lyme disease. International Journal of Systematic and Evolutionary Microbiology, 34(4), 496-497. http://dx.doi.org/10.1099/00207713-34-4-496

Kalish, R. (2012). Lyme disease. American College of Rheumatology. Retrieved September 15, 2012, from http://www.rheumatology.org/practice/clinical/patients/diseases_and_conditions/lymedisease.asp.

Kilpatrick, A. M. (2011). Globalization, land use, and the invasion of West Nile Virus. Science, 334(6054), 323-327. http://dx.doi.org/10.1126/science. 1201010

Krupka, M., Raska, M., Belakova, J., Horynova, M., Novotny, R., \& Weigl, E. (2007). Biological aspects of Lyme disease spirochetes: unique bacteria of the Borrelia burgdorferi species group. Biomedical Papers, 151(2), 175-186.

Kurnatowski, P., Warpechowska, M., \& Kurnatowska, A. J. (2011). Knowledge on Lyme disease among foresters. International journal of occupational medicine and environmental health, 24(1), 78-93. http://dx.doi.org/10.2478/s13382-011-0001-7

Lyme disease.org (n.d.). Lyme disease Diagnosis. Retrieved May 13, 2012, from http://www.lymedisease.org/lyme101/lyme_disease/lyme_diagnosis.html

Michigan Official Website (Michigan.Gov). (n.d.). Lyme disease and White-tailed Deer. Retrieved May 22, 2012, from http://www.michigan.gov/emergingdiseases/0,4579,7-186-25890_26140-75872--,00.html

Michigan State University Diagnostic Services. (n.d.). Deer Tick or Black-legged Tick (Ixodes scapularis). (Modified from the Ohio State University Extension Fact Sheet Black-Legged Tick HYG-2147-98 by W. F. Lyon, R. L. Berry, \& R. A. Restifo. OSU Entomology - 1991). Retrieved May 12, 2012, from www.pestid.msu.edu/InsectsArthropods/DeerTickorBlackleggedTickIxodesscapularis/tabid/279/Default.asp $\mathrm{x}$

Milovanovic, A., Milovanovic, J., Obrenovic, S., Milovanovic, A., Simonovic, P., Cemerikic, D., ... Popevic, M. (2010). Lyme Neuroborreliosis. Acta Veterinaria, 61, 89-98. doi: 10.2298/AVB1101089 M

Minnesota Department of Health. (2011). Blacklegged Ticks (Deer Tick, Bear Tick). Retrieved May 22, 2012, from http://www.health.state.mn.us/divs/idepc/dtopics/tickborne/ticks.html

National Wildlife Federation. (n.d.). American Robin. Retrieved May 12, 2012, from www.nwf.org/Wildlife/Wildlife-Library/Birds/American-Robin.aspx

North American Breeding Bird Survey. (n.d.). Retrieved September 12, 2011, from www.pwrc.usgs.gov/BBS/

Rice, W. R. (1989). Analyzing tables of statistical tests. Evolution, 43(1), 223-225.

Seattle Audubon Society. (n.d.). Bird Web. Gray Catbird. Retrieved May 15, 2012, from http://birdweb.org/birdweb/ bird/gray catbird

Stafford III, K. C. (2001). Ticks. Connecticut Agricultural Experiment Station. Retrieved May 22, 2012, from www.ct.gov/caes/lib/caes/documents/publications/fact_sheets/ticks.pdf

Terres, J. K. (1996). Encyclopedia of North American Birds (6th ed.). National Audubon Society.

The Center of Food Security and Public Health. (2011). Lyme disease, Lyme Borreliosis, Lyme Arthritis, Erythema Migrans with Polyarthritis. Retrieved September 5, 2012, from www.cfsph.iastate.edu/Factsheets/pdfs/lyme_disease.pdf

U.S. Department of Health and Human Services. Center for Disease Control and Prevention. (2012). Lyme disease: A Public Information Guide. Retrieved May 20, 2012, from http://www.cdc.gov/lyme/resources/brochure/508_LD_Brochure.pdf

U.S. Fish and Wildlife Service. (1998). Migration of Birds. Retrieved May 19, 2012, from http://library.fws.gov/Circulars/Mig_of_Birds_16_98.pdf

\section{Copyrights}

Copyright for this article is retained by the author(s), with first publication rights granted to the journal.

This is an open-access article distributed under the terms and conditions of the Creative Commons Attribution license (http://creativecommons.org/licenses/by/4.0/). 